\title{
The Romanian Society of Internal Medicine's Choosing Wisely Campaign
}

\author{
CATERINA DELCEA ${ }^{1,2,3}$, CAMELIA BADEA $^{1,2}$, CIPRIAN JURCUT $^{4}$, ADRIAN PURCAREA $^{5,6}$, \\ SILVIA SOVAILA ${ }^{5,6}$, EMMA WEISS $^{1,7}$, ELENA ALISTAR $^{8}$, HORIA BALAN $^{1,9}$, CRISTIAN BAICUS $^{1,2,10}$ \\ "Carol Davila" University of Medicine and Pharmacy, Bucharest, Romania \\ ${ }^{2}$ Internal Medicine Department, "Colentina" Clinical Hospital \\ ${ }^{3}$ CDPC Cardiology Laboratory, "Colentina" Clinical Hospital \\ ${ }^{4}$ Internal Medicine Department, "Dr Carol Davila” Central University Emergency Military Hospital, Bucharest, Romania \\ ${ }^{5}$ Internal Medicine, Charleville Regional Hospital, France \\ ${ }^{6}$ Internist.ro Clinic, Brasov, Romania \\ ${ }^{7}$ Internal Medicine Department, Clinical University Emergency Hospital, Bucharest, Romania \\ ${ }^{8}$ Internal Medicine Department, Emergency Hospital, Bacău, Romania \\ ${ }^{9}$ Internal Medicine Department, Clinical Emergency Hospital Ilfov, Bucharest, Romania \\ ${ }^{10}$ Réseau d'Epidémiologie Clinique International Francophone (RECIF), Bucharest, Romania
}

\begin{abstract}
Quality of care in medicine is not necessarily proportional to quantity of care and excess is often useless or even more, potentially detrimental to our patients. Adhering to the European Federation of Internal Medicine's initiative, the Romanian Society of Internal Medicine (SRMI) launched the Choosing Wisely in Internal Medicine Campaign, aiming to cut down diagnostic procedures or therapeutics overused in our country. A Working Group was formed and from 200 published recommendations from previous international campaigns, 36 were voted as most important. These were submitted for voting to the members of the SRMI and posted on a social media platform. After the two voting rounds, the top six recommendations were established.

These were:

1. Stop medicines when no further benefit is achieved or the potential harms outweigh the potential benefits for the individual patient.

2. Don't use antibiotics in patients with recent $C$. difficile without convincing evidence of need.

3. Don't regularly prescribe bed rest and inactivity following injury and/or illness unless there is scientific evidence that harm will result from activity. Promote early mobilization.

4. Don't initiate an antibiotic without an identified indication and a predetermined length of treatment or review date.

5. Don't prescribe opioids for treatment of chronic or acute pain for sensitive jobs such as operating motor vehicles, forklifts, cranes or other heavy equipment.

6. Transfuse red cells for anemia only if the hemoglobin concentration is less than $7 \mathrm{~g} / \mathrm{dL}$ or if the patient is hemodynamically unstable or has significant cardiovascular or respiratory comorbidity. Don't transfuse more units of blood than absolutely necessary.
\end{abstract}

Key words: Choosing Wisely, Internal Medicine, Less is more.

\section{INTRODUCTION}

Progress in medicine, especially concerning diagnostic procedures and therapeutic interventions, led to some extent of overuse and misuse in all clinical fields. Apart from the associated economic burden, this practice is increasing the prevalence of poor-quality care, as unnecessary procedures or therapies can harm patients.

In 2009 the National Physicians Alliance in the United States initiated the "Promoting Good Stewardship in Medicine" project to identify five medical practices that were inappropriately used, that could be amended and improved, as an attempt to enhance the quality of clinical care, to decrease the associated harm and to diminish the unnecessary costs [1]. The first top 5 lists were issued for Family Medicine, Internal Medicine and Surgery, emphasizing the significant health benefits and reduced risks and costs associated with practicing both evidence-based and reasonable medicine [2].

In 2012 the American Board of Internal Medicine launched the Choosing Wisely Campaign as an attempt to reduce waste and redundancy in clinical practice [3]. The initiative became global as other medical societies from all over the world also set out to cut down the excess of unnecessary medical investigations and potentially harmful effects of inadequate treatment.

In 2017, the European Federation of Internal Medicine launched the Choosing Wisely Project 
among its member societies. In March 2017, the Romanian Society of Internal Medicine (SRMI) joined the campaign. Its aim was to encourage the judicious use of diagnostic tests and therapeutics when they are truly necessary, evidence-based, and with the smallest possible risk of harm for the patient.

For this purpose, we assessed the awareness and preferences of Romanian internists concerning the Choosing Wisely recommendations.

\section{MATERIAL AND METHODS}

A Choosing Wisely Internal Medicine Romania Working Group was established. It consisted of eight Internal Medicine specialists, both junior as well as senior physicians, from university-affiliated as well as non-university affiliated hospitals and clinics around the country.

In March 2017 two members of the Working Group performed a literature search, accessed and collected all Choosing Wisely lists published until then from the Internal Medicine and related subspecialties' societies in the United States [3], Canada [4], Australia [5], United Kingdom [6], the Italian Society of Internal Medicine [7], the Italian Federation of Associations of Hospital Doctors in Internal Medicine [8] and the Swiss Society of General Internal Medicine [9]. Recommendations from Surgery and related subspecialties, Pediatrics, Imaging and Radiology, Genetics, Ophthalmology, Dermatology and Dentistry Societies were not collected. From the initial list, recommendations concerning Intensive Care, Oncology, Psychiatry, and Interventional Cardiology were excluded. Recommendations referring to specialized diagnostic procedures or therapies were also excluded. Repeated recommendations were excluded.

After the initial selection process, a list of 200 recommendations was generated. Considering the multitude of items on this list, we assumed a low response rate should we have sent the survey to all Romanian internists. Therefore, the eight members of the Working Group received the list and were asked to grade each recommendation according to importance in clinical practice and applicability in our country, using a 10-point Likert scale (1 for a recommendation with very low importance to 10 for a very important recommendation). In order to avoid grading bias, each member received the list with the recommendations arranged randomly.

After the first phase of the evaluation, the top 36 recommendations with the highest average score were selected, including all recommendations with the same score. Since some of them highly resembled in regard to the targeted intervention as well as the overall message, after consulting all members of the panel, a decision was made to combine the very similar ones as one single recommendation. Therefore, out of the 36 highest rated indications by the Working Group, 31 recommendations were considered of the highest interest for Internal Medicine clinical practice in Romania.

During the second phase of the selection process, the ensuing list was sent by e-mail to all SRMI members in the form of an online questionnaire. They also received information about the Choosing Wisely Romania project and the aims and importance of the Campaign. They were asked to grade each recommendation from 1 (very low importance) to 10 (very high importance) based on their medical expertise and clinical judgement. The online questionnaire alongside the information about the Choosing Wisely Romania project was also disseminated on a social media platform.

During the last phase of the selection process, the average score of each recommendation was calculated. The recommendations with the highest average scores were selected as the Top 6 Choosing Wisely Romania recommendations.

\section{RESULTS}

Our initial search included 177 lists of Choosing Wisely recommendations from 171 societies from 6 countries (Figure 1). After evaluation of applicability to the clinical practice in Internal Medicine, from a total of 593 recommendations, 200 were reviewed and graded by the Choosing Wisely Romania - Internal Medicine Working Group.

Of the top 36 recommendations ranked by the Group (Table 1), seven were identified to be very similar regarding the targeted intervention and the general message. Therefore, recommendations 1 and 22 , respectively $3,7,9,24$ and 25 were combined, resulting in two joined recommendations, 1 and 3. The resulting 31 recommendations were integrated into an online questionnaire and were emailed to the 467 registered members of SRMI and shared on a social media platform. Among the SRMI members, the response rate was $37.68 \%$ (176 physicians). From the social media platform, other 68 physicians completed the questionnaire. Demographics and characteristics of all 244 responders are listed in Table 2. 
After retrieving the votes, the average score was calculated for each recommendation for the entire group of respondents, and separately for the SRMI members and the respondents from the social media platform (Table 3 ).

The top six recommendations ranked from the entire group of respondents were selected as the
Choosing Wisely Romania recommendations for Internal Medicine (Table 4), mostly corresponding to top 6 ranked recommendations in each subgroup as well (Tables 5 and 6). Four of these recommendations were found in each ranking, while two of them were present in the entire group and one of the subgroups' top-rated selection.

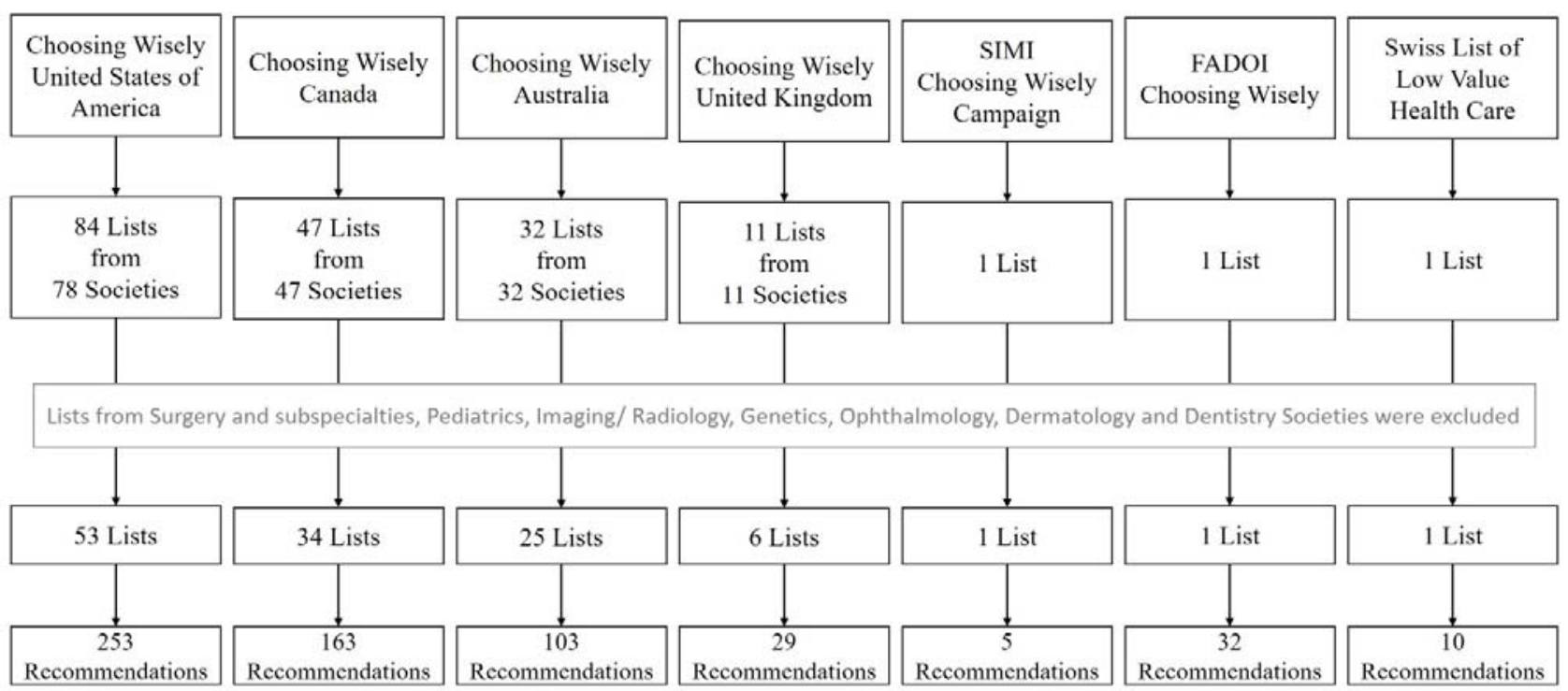

Figure 1.177 lists of Choosing Wisely recommendations from 171 societies from 6 countries.

Table 1

List of top $31^{\text {st }}$ Choosing Wisely Internal Medicine Romania recommendations ranked by the Working Group

\begin{tabular}{|c|c|c|}
\hline Ranking & Recommendation & $\begin{array}{l}\text { Average } \\
\text { score }\end{array}$ \\
\hline 1 & $\begin{array}{l}\text { Transfuse red cells for anemia only if the hemoglobin concentration is less than } 7 \mathrm{~g} / \mathrm{dL} \text { or if the patient is } \\
\text { hemodynamically unstable or has significant cardiovascular or respiratory comorbidity. }\end{array}$ & 9.37 \\
\hline 2 & $\begin{array}{l}\text { Do not routinely prescribe lipid-lowering medications in patients with a limited life expectancy; above } \\
85 \text { years the risk of cognitive impairment, falls, neuropathy, muscular damage due to statins increases. }\end{array}$ & 9.00 \\
\hline 3 & $\begin{array}{l}\text { Don't continue or add long-term medications unless there is an appropriate indication and a reasonable } \\
\text { expectation of benefit in the individual patient. }\end{array}$ & 9.00 \\
\hline 4 & $\begin{array}{l}\text { Don't order an erythrocyte sedimentation rate to look for inflammation in patients with undiagnosed } \\
\text { conditions. Order a C-reactive protein to detect acute phase inflammation. }\end{array}$ & 8.87 \\
\hline 5 & $\begin{array}{l}\text { Don't prescribe angiotensin converting enzyme inhibitors in combination with angiotensin II receptor } \\
\text { blockers for the treatment of hypertension, diabetic nephropathy and heart failure. }\end{array}$ & 8.87 \\
\hline 6 & Do not perform a D-dimer test without a definite indication. & 8.75 \\
\hline 7 & Don't prescribe a medication without conducting a drug regimen review. & 8.75 \\
\hline 8 & $\begin{array}{l}\text { Don't use antibiotics in patients with recent } C \text {. difficile without convincing evidence of need. Antibiotics pose } \\
\text { a high risk of C. difficile recurrence. }\end{array}$ & 8.75 \\
\hline 9 & Reduce use of multiple concurrent therapeutics (hyper-polypharmacy). & 8.62 \\
\hline 10 & $\begin{array}{l}\text { Don't initiate an antibiotic without an identified indication and a predetermined length of treatment or review } \\
\text { date. }\end{array}$ & 8.62 \\
\hline 11 & Don't let older adults lie in bed or only get up to a chair during their hospital stay. & 8.50 \\
\hline 12 & Don't use expensive medications when an equally effective and lower-cost medication is available. & 8.50 \\
\hline 13 & $\begin{array}{l}\text { Don't prescribe antibiotics for asymptomatic bacteriuria in non-pregnant patients or in patients not } \\
\text { undergoing an endoscopic urological procedure. }\end{array}$ & 8.37 \\
\hline 14 & $\begin{array}{l}\text { Don't treat with an anticoagulant for more than three months a patient with a first venous thromboembolism } \\
\text { occurring in the setting of a major transient risk factor. }\end{array}$ & 8.37 \\
\hline 15 & Don't recommend regular use of oral non-steroidal anti-inflammatory medicines (NSAIDs) in older people. & 8.37 \\
\hline 16 & Do not routinely prescribe colloid (albumin, dextrans, starches) for volume replacement, prefer crystalloid (saline). & 8.37 \\
\hline 17 & $\begin{array}{l}\text { Stop medicines when no further benefit will be achieved or the potential harms outweigh the potential benefits } \\
\text { for the individual patient. }\end{array}$ & 8.37 \\
\hline 18 & $\begin{array}{l}\text { For pharmacological treatment of patients with gastroesophageal reflux disease long-term acid suppression } \\
\text { therapy (proton pump inhibitors or histamine } 2 \text { receptor antagonists) should be titrated to the lowest effective } \\
\text { dose needed to achieve therapeutic goals. }\end{array}$ & 8.37 \\
\hline
\end{tabular}


Table 1 (continued)

\begin{tabular}{|c|c|c|}
\hline 19 & $\begin{array}{l}\text { Do not use NSAIDs in subjects with arterial hypertension, heart failure, renal insufficiency from any cause, } \\
\text { including diabetes; prefer safer drugs such as paracetamol, tramadol, short term narcotic analgesics. }\end{array}$ & 8.37 \\
\hline 20 & Don't continue antibiotics beyond 72 hours in hospitalized patients unless patient has a clear evidence of infection. & 8.37 \\
\hline 21 & Don't use whole-body scans for early tumor detection in asymptomatic patients. & 8.25 \\
\hline 22 & Don't transfuse more units of blood than absolutely necessary. & 8.25 \\
\hline 23 & $\begin{array}{l}\text { Don't regularly prescribe bed rest and inactivity following injury and/or illness unless there is scientific } \\
\text { evidence that harm will result from activity. Promote early mobilization. }\end{array}$ & 8.25 \\
\hline 24 & $\begin{array}{l}\text { To avoid adverse medication interactions and adverse drug events in cases of polypharmacy, do not prescribe } \\
\text { medication without conducting a drug regime review. }\end{array}$ & 8.25 \\
\hline 25 & Recognize and stop the prescribing cascade. & 8.25 \\
\hline 26 & $\begin{array}{l}\text { When considering risk modifying treatment in primary prevention, for example treatment for blood pressure, } \\
\text { cholesterol or bone density, share the option to have treatment or not, before prescribing. Decision aids exist } \\
\text { to support this process for doctors and patients. }\end{array}$ & 8.25 \\
\hline 27 & $\begin{array}{l}\text { Don't prescribe opioids for treatment of chronic or acute pain for sensitive jobs such as operating motor } \\
\text { vehicles, forklifts, cranes or other heavy equipment. }\end{array}$ & 8.25 \\
\hline 28 & $\begin{array}{l}\text { Don't continue treatment for hepatic encephalopathy indefinitely after an initial episode with an identifiable } \\
\text { precipitant. }\end{array}$ & 8.12 \\
\hline 29 & $\begin{array}{l}\text { Don't order diagnostic tests at regular intervals (such as every day), but rather in response to specific clinical } \\
\text { questions. }\end{array}$ & 8.12 \\
\hline 30 & Don't diagnose or manage asthma without spirometry. & 8.12 \\
\hline 31 & $\begin{array}{l}\text { Don't place, or leave in place, urinary catheters for incontinence or convenience or monitoring for output for } \\
\text { non-critically ill patients (acceptable indications: critical illness, obstruction, hospice, perioperatively for }<2 \\
\text { days for urologic procedures; use weights instead to monitor diuresis). }\end{array}$ & 8.12 \\
\hline 32 & $\begin{array}{l}\text { Do not conduct thrombophilia testing in adult patients under the age of } 50 \text { unless the first episode of venous } \\
\text { thromboembolism: } \\
\text { - occurs in the absence of major transient risk factors (surgery, immobility), or } \\
\text { - occurs in the absence of estrogen-provocation, or } \\
\text { - occurs at an unusual site }\end{array}$ & 8.12 \\
\hline 33 & $\begin{array}{l}\text { Don't recommend bed rest following diagnosis of acute deep vein thrombosis (DVT) after the initiation of } \\
\text { anti-coagulation therapy unless significant medical concerns are present. }\end{array}$ & 8.12 \\
\hline 34 & $\begin{array}{l}\text { When patients are particularly frail or in their last year of life, unless there is a clear preference otherwise by } \\
\text { the patient or advocate, discuss with the patient and family/ caregivers the option of decreasing the number of } \\
\text { medicines to only those used for control of symptoms. }\end{array}$ & 8.12 \\
\hline 35 & $\begin{array}{l}\text { Don't screen for renal artery stenosis in patients without resistant hypertension and with normal renal } \\
\text { function, even if known atherosclerosis is present. }\end{array}$ & 8.12 \\
\hline 36 & $\begin{array}{l}\text { Don't routinely prescribe intravenous forms of highly bioavailable antimicrobial agents for patients who can } \\
\text { reliably take and absorb oral medications. }\end{array}$ & 8.12 \\
\hline
\end{tabular}

Table 2

General characteristics of respondents

\begin{tabular}{|c|c|c|c|}
\hline & $\begin{array}{l}\text { Entire Group } \\
\quad \mathrm{N}=244\end{array}$ & $\begin{array}{c}\text { SRMI } \\
\text { E-mail Responders } \\
\mathrm{N}=176\end{array}$ & $\begin{array}{c}\text { Social Media Platform } \\
\text { Responders } \\
\mathrm{N}=68\end{array}$ \\
\hline Mean age, years & $41.8 \pm 11.7$ & $44.6 \pm 11.1$ & $33.9 \pm 9.9$ \\
\hline $\begin{array}{l}\text { Gender, N (\%) } \\
\text { Female } \\
\text { Male } \\
\text { Not declared }\end{array}$ & $\begin{array}{c}184(75.4 \%) \\
54(22.13 \%) \\
6(2.46 \%)\end{array}$ & $\begin{array}{c}137(77.9 \%) \\
37(21.0 \%) \\
2(1.1 \%)\end{array}$ & $\begin{array}{c}47(69.1 \%) \\
17(25 \%) \\
4(5.9 \%)\end{array}$ \\
\hline $\begin{array}{l}\text { Location, N (\%) } \\
\text { Bucharest } \\
\text { Iasi } \\
\text { Others }\end{array}$ & $\begin{array}{l}127(52 \%) \\
19(7.8 \%) \\
98(40.2 \%)\end{array}$ & $\begin{array}{l}83(47.2 \%) \\
16(9.1 \%) \\
77(43.7 \%)\end{array}$ & $\begin{array}{c}44(64.7 \%) \\
3(4.4 \%) \\
21(30.9 \%)\end{array}$ \\
\hline $\begin{array}{l}\text { Specialty, N (\%) } \\
\text { Internal Medicine } \\
\text { Rheumatology } \\
\text { Family Medicine } \\
\text { Cardiology } \\
\text { Others }\end{array}$ & $\begin{array}{c}112(45.9 \%) \\
33(13.5 \%) \\
22(9 \%) \\
22(9 \%) \\
55(22.6 \%)\end{array}$ & $\begin{array}{l}68(38.6 \%) \\
24(13.6 \%) \\
22(12.5 \%) \\
18(10.2 \%) \\
44(25.1 \%)\end{array}$ & $\begin{array}{c}44(64.7 \%) \\
9(13.2 \%) \\
- \\
4(5.9 \%) \\
11(16.2 \%)\end{array}$ \\
\hline $\begin{array}{l}\text { Clinical setting, N (\%) } \\
\text { University hospital } \\
\text { County hospital } \\
\text { City hospital } \\
\text { Outpatient clinic } \\
\text { Not declared }\end{array}$ & $\begin{array}{c}134(55 \%) \\
21(8.7 \%) \\
10(4 \%) \\
74(30.3 \%) \\
5(2 \%)\end{array}$ & $\begin{array}{c}88(50 \%) \\
16(9 \%) \\
9(5 \%) \\
63(36 \%) \\
-\end{array}$ & $\begin{array}{c}46(67.6 \%) \\
5(7.4 \%) \\
1(1.5 \%) \\
11(16.2 \%) \\
5(7.3)\end{array}$ \\
\hline
\end{tabular}


Table 2 (continued)

\begin{tabular}{|c|c|c|c|}
\hline Professional ranking, N (\%) & & & \\
\hline Senior specialist & $106(43.4 \%)$ & $93(52.8 \%)$ & $13(19.1 \%$ \\
\hline Specialist & $71(29.1 \%)$ & $56(31.8 \%)$ & $15(22.1 \%$ \\
\hline Resident & $60(24.6 \%)$ & $24(13.6 \%)$ & $36(52.9 \%$ \\
\hline Not declared & $7(2.9 \%)$ & $3(1.8 \%)$ & $4(5.9 \%)$ \\
\hline Mean time practicing medicine & $14.3 \pm 9.8$ & $17.4 \pm 10.7$ & $9.5 \pm 5.3$ \\
\hline
\end{tabular}

Table 3

List of top $31^{\text {st }}$ Choosing Wisely Internal Medicine Romania recommendations ranked by the respondents

\begin{tabular}{|c|c|c|c|c|c|}
\hline No. & Recommendation & \begin{tabular}{c|}
$\begin{array}{c}\text { Total } \\
\text { number } \\
\text { of } \\
\text { responses }\end{array}$ \\
\end{tabular} & $\begin{array}{c}\text { General } \\
\text { average } \\
\text { score }\end{array}$ & $\begin{array}{c}\text { Email } \\
\text { average } \\
\text { score }\end{array}$ & $\begin{array}{l}\text { Social } \\
\text { media } \\
\text { average } \\
\text { score }\end{array}$ \\
\hline 1 & $\begin{array}{l}\text { Stop medicines when no further benefit will be achieved or the potential harms } \\
\text { outweigh the potential benefits for the individual patient. }\end{array}$ & 182 & 9.42 & 9.39 & 9.52 \\
\hline 2 & $\begin{array}{l}\text { Don't use antibiotics in patients with recent C. difficile without convincing } \\
\text { evidence of need. Antibiotics pose a high risk of C. difficile recurrence. }\end{array}$ & 175 & 9.40 & 9.48 & 9.14 \\
\hline 3 & $\begin{array}{l}\text { Don't regularly prescribe bed rest and inactivity following injury and/or illness } \\
\text { unless there is scientific evidence that harm will result from activity. Promote early } \\
\text { mobilization. }\end{array}$ & 180 & 9.18 & 9.16 & 9.23 \\
\hline 4 & $\begin{array}{l}\text { Don't initiate an antibiotic without an identified indication and a predetermined } \\
\text { length of treatment or review date. }\end{array}$ & 179 & 9.13 & 9.13 & 9.14 \\
\hline 5 & $\begin{array}{l}\text { Don't prescribe opioids for treatment of chronic or acute pain for sensitive jobs } \\
\text { such as operating motor vehicles, forklifts, cranes or other heavy equipment. }\end{array}$ & 176 & 9.09 & 9.11 & 9.04 \\
\hline 6 & $\begin{array}{l}\text { Transfuse red cells for anemia only if the hemoglobin concentration is less than } \\
7 \mathrm{~g} / \mathrm{dL} \text { or if the patient is hemodynamically unstable or has significant } \\
\text { cardiovascular or respiratory comorbidity. Don't transfuse more units of blood than } \\
\text { absolutely necessary. }\end{array}$ & 175 & 9.09 & 9.26 & 8.51 \\
\hline 7 & Do not perform a D-dimer test without a definite indication. & 175 & 9.07 & 9.12 & 8.90 \\
\hline 8 & $\begin{array}{l}\text { Don't continue or add long-term medications unless there is an appropriate } \\
\text { indication and a reasonable expectation of benefit in the individual patient. Don't } \\
\text { prescribe a medication without conducting a drug regimen review. Reduce use of } \\
\text { multiple concurrent therapeutics (hyper-polypharmacy). }\end{array}$ & 181 & 9.06 & 9.19 & 8.61 \\
\hline 9 & $\begin{array}{l}\text { Do not routinely prescribe colloid (albumin, dextrans, starches) for volume } \\
\text { replacement, prefer crystalloid (saline). }\end{array}$ & 167 & 9.01 & 9.14 & 8.64 \\
\hline 10 & $\begin{array}{l}\text { Don't routinely prescribe intravenous forms of highly bioavailable antimicrobial } \\
\text { agents for patients who can reliably take and absorb oral medications. }\end{array}$ & 178 & 8.97 & 9.11 & 8.52 \\
\hline 11 & $\begin{array}{l}\text { Don't order diagnostic tests at regular intervals (such as every day), but rather in } \\
\text { response to specific clinical questions. }\end{array}$ & 180 & 8.96 & 9.02 & 8.73 \\
\hline 12 & Don't diagnose or manage asthma without spirometry. & 163 & 8.94 & 8.91 & 9.05 \\
\hline 13 & $\begin{array}{l}\text { Don't place, or leave in place, urinary catheters for incontinence or convenience or } \\
\text { monitoring for output for non-critically ill patients (acceptable indications: critical } \\
\text { illness, obstruction, hospice, perioperatively for }<2 \text { days for urologic procedures; } \\
\text { use weights instead to monitor diuresis). }\end{array}$ & 165 & 8.89 & 8.97 & 8.62 \\
\hline 14 & $\begin{array}{l}\text { Don't prescribe angiotensin converting enzyme inhibitors in combination with } \\
\text { angiotensin II receptor blockers for the treatment of hypertension, diabetic } \\
\text { nephropathy and heart failure. }\end{array}$ & 172 & 8.80 & 9.00 & 8.40 \\
\hline 15 & $\begin{array}{l}\text { For pharmacological treatment of patients with gastroesophageal reflux disease } \\
\text { long-term acid suppression therapy (proton pump inhibitors or histamine } 2 \text { receptor } \\
\text { antagonists) should be titrated to the lowest effective dose needed to achieve } \\
\text { therapeutic goals. }\end{array}$ & 173 & 8.80 & 8.78 & 8.85 \\
\hline 16 & $\begin{array}{l}\text { Don't recommend bed rest following diagnosis of acute deep vein thrombosis } \\
\text { (DVT) after the initiation of anti-coagulation therapy unless significant medical } \\
\text { concerns are present. }\end{array}$ & 172 & 8.76 & 8.79 & 8.65 \\
\hline 17 & Don't let older adults lie in bed or only get up to a chair during their hospital stay. & 176 & 8.73 & 8.72 & 8.78 \\
\hline 18 & $\begin{array}{l}\text { Don't prescribe antibiotics for asymptomatic bacteriuria in non-pregnant patients } \\
\text { or in patients not undergoing an endoscopic urological procedure. }\end{array}$ & 171 & 8.69 & 8.61 & 8.92 \\
\hline 19 & $\begin{array}{l}\text { Do not conduct thrombophilia testing in adult patients under the age of } 50 \text { unless } \\
\text { the first episode of venous thromboembolism: } \\
\text { - occurs in the absence of major transient risk factors (surgery, immobility), or } \\
\text { - occurs in the absence of estrogen-provocation, or } \\
\text { - occurs at an unusual site }\end{array}$ & 164 & 8.67 & 8.67 & 8.65 \\
\hline 20 & $\begin{array}{l}\text { When considering risk modifying treatment in primary prevention, for example } \\
\text { treatment for blood pressure, cholesterol or bone density, share the option to have } \\
\text { treatment or not, before prescribing. Decision aids exist to support this process for } \\
\text { doctors and patients. }\end{array}$ & 166 & 8.55 & 8.66 & 8.17 \\
\hline
\end{tabular}


Table 3 (continued)

\begin{tabular}{|c|c|c|c|c|c|}
\hline 21 & $\begin{array}{l}\text { Do not use NSAIDs in subjects with arterial hypertension, heart failure, renal } \\
\text { insufficiency from any cause, including diabetes; prefer safer drugs such as } \\
\text { paracetamol, tramadol, short term narcotic analgesics. }\end{array}$ & 177 & 8.52 & 8.48 & 8.65 \\
\hline 22 & $\begin{array}{l}\text { Don't continue antibiotics beyond } 72 \text { hours in hospitalized patients unless patient has } \\
\text { a clear evidence of infection. }\end{array}$ & 169 & 8.36 & 8.23 & 8.75 \\
\hline 23 & $\begin{array}{l}\text { Don't use expensive medications when an equally effective and lower-cost } \\
\text { medication is available. }\end{array}$ & 181 & 8.35 & 8.26 & 8.66 \\
\hline 24 & $\begin{array}{l}\text { Don't screen for renal artery stenosis in patients without resistant hypertension and } \\
\text { with normal renal function, even if known atherosclerosis is present. }\end{array}$ & 172 & 8.34 & 8.48 & 7.87 \\
\hline 25 & $\begin{array}{l}\text { Don't treat with an anticoagulant for more than three months a patient with a first } \\
\text { venous thromboembolism occurring in the setting of a major transient risk factor. }\end{array}$ & 167 & 8.32 & 8.28 & 8.48 \\
\hline 26 & $\begin{array}{l}\text { Don't use whole-body scans (CT, MRi, PET) for early tumor detection in } \\
\text { asymptomatic patients. }\end{array}$ & 177 & 8.32 & 8.53 & 7.63 \\
\hline 27 & $\begin{array}{l}\text { Don't continue treatment for hepatic encephalopathy indefinitely after an initial } \\
\text { episode with an identifiable precipitant. }\end{array}$ & 149 & 8.22 & 8.27 & 8.08 \\
\hline 28 & $\begin{array}{l}\text { When patients are particularly frail or in their last year of life, unless there is a clear } \\
\text { preference otherwise by the patient or advocate, discuss with the patient and family/ } \\
\text { caregivers the option of decreasing the number of medicines to only those used for } \\
\text { control of symptoms. }\end{array}$ & 175 & 7.99 & 7.96 & 8.09 \\
\hline 29 & $\begin{array}{l}\text { Don't order an erythrocyte sedimentation rate to look for inflammation in patients } \\
\text { with undiagnosed conditions. Order a C-reactive protein to detect acute phase } \\
\text { inflammation. }\end{array}$ & 180 & 7.92 & 7.92 & 7.90 \\
\hline 30 & $\begin{array}{l}\text { Do not routinely prescribe lipid-lowering medications in patients with a limited life } \\
\text { expectancy; above } 85 \text { years the risk of cognitive impairment, falls, neuropathy, } \\
\text { muscular damage due to statins increases. }\end{array}$ & 172 & 7.91 & 8.01 & 7.60 \\
\hline 31 & $\begin{array}{l}\text { Don't recommend regular use of oral non-steroidal anti-inflammatory medicines } \\
\text { (NSAIDs) in older people. }\end{array}$ & 177 & 7.76 & 7.60 & 8.32 \\
\hline
\end{tabular}

Table 4

List of final 6 Choosing Wisely Internal Medicine Romania Recommendations

\begin{tabular}{|c|l|c|}
\hline Ranking & \multicolumn{1}{|c|}{ Recommendation } & $\begin{array}{c}\text { Average } \\
\text { Score }\end{array}$ \\
\hline 1 & $\begin{array}{l}\text { Stop medicines when no further benefit will be achieved or the potential harms outweigh the potential benefits } \\
\text { for the individual patient. }\end{array}$ & 9.42 \\
\hline 2 & $\begin{array}{l}\text { Don't use antibiotics in patients with recent C. difficile without convincing evidence of need. Antibiotics pose } \\
\text { a high risk of } C \text {. difficile recurrence. }\end{array}$ & 9.40 \\
\hline 3 & $\begin{array}{l}\text { Don't regularly prescribe bed rest and inactivity following injury and/or illness unless there is scientific } \\
\text { evidence that harm will result from activity. Promote early mobilization. }\end{array}$ & 9.18 \\
\hline 4 & $\begin{array}{l}\text { Don't initiate an antibiotic without an identified indication and a predetermined length of treatment or review date. } \\
\text { von't prescribe opioids for treatment of chronic or acute pain for sensitive jobs such as operating motor } \\
\text { vehicles, forklifts, cranes or other heavy equipment. }\end{array}$ & 9.13 \\
\hline 6 & $\begin{array}{l}\text { Transfuse red cells for anemia only if the hemoglobin concentration is less than 7 g/dL or if the patient is } \\
\text { hemodynamically unstable or has significant cardiovascular or respiratory comorbidity. Don't transfuse more } \\
\text { units of blood than absolutely necessary. }\end{array}$ & 9.09 \\
\hline
\end{tabular}

Table 5

Top 6 ranked recommendations from the email participants

\begin{tabular}{|c|l|c|}
\hline Ranking & \multicolumn{1}{|c|}{ Recommendation } & $\begin{array}{c}\text { Average } \\
\text { Score }\end{array}$ \\
\hline 1 & $\begin{array}{l}\text { Don't use antibiotics in patients with recent C. difficile without convincing evidence of need. Antibiotics pose } \\
\text { a high risk of C. difficile recurrence. }\end{array}$ & 9.48 \\
\hline 2 & $\begin{array}{l}\text { Stop medicines when no further benefit will be achieved or the potential harms outweigh the potential benefits } \\
\text { for the individual patient. }\end{array}$ & 9.39 \\
\hline 3 & $\begin{array}{l}\text { Transfuse red cells for anemia only if the hemoglobin concentration is less than 7 g/dL or if the patient is } \\
\text { hemodynamically unstable or has significant cardiovascular or respiratory comorbidity. Don't transfuse more } \\
\text { units of blood than absolutely necessary. }\end{array}$ & 9.26 \\
\hline 4 & $\begin{array}{l}\text { Don't continue or add long-term medications unless there is an appropriate indication and a reasonable } \\
\text { expectation of benefit in the individual patient. Don't prescribe a medication without conducting a drug } \\
\text { regimen review. Reduce use of multiple concurrent therapeutics (hyper-polypharmacy). }\end{array}$ & 9.19 \\
\hline 5 & $\begin{array}{l}\text { Don't regularly prescribe bed rest and inactivity following injury and/or illness unless there is scientific } \\
\text { evidence that harm will result from activity. Promote early mobilization. }\end{array}$ & 9.16 \\
\hline 6 & $\begin{array}{l}\text { Don't initiate an antibiotic without an identified indication and a predetermined length of treatment or review } \\
\text { date. }\end{array}$ & 9.13 \\
\hline
\end{tabular}


Table 6

Top 6 ranked recommendations from the social media participants

\begin{tabular}{|c|l|c|}
\hline Ranking & \multicolumn{1}{|c|}{ Recommendation } & $\begin{array}{c}\text { Average } \\
\text { Score }\end{array}$ \\
\hline 1 & $\begin{array}{l}\text { Stop medicines when no further benefit will be achieved or the potential harms outweigh the potential benefits } \\
\text { for the individual patient. }\end{array}$ & 9.52 \\
\hline 2 & $\begin{array}{l}\text { Don't regularly prescribe bed rest and inactivity following injury and/or illness unless there is scientific } \\
\text { evidence that harm will result from activity. Promote early mobilization. }\end{array}$ & 9.23 \\
\hline 3 & $\begin{array}{l}\text { Don't use antibiotics in patients with recent } C \text {. difficile without convincing evidence of need. Antibiotics pose } \\
\text { a high risk of } C \text {. difficile recurrence. }\end{array}$ & 9.14 \\
\hline 4 & Don't initiate an antibiotic without an identified indication and a predetermined length of treatment or review date. & 9.14 \\
\hline 5 & Don't diagnose or manage asthma without spirometry. & 9.05 \\
\hline 6 & $\begin{array}{l}\text { Don't prescribe opioids for treatment of chronic or acute pain for sensitive jobs such as operating motor } \\
\text { vehicles, forklifts, cranes or other heavy equipment. }\end{array}$ & 9.04 \\
\hline
\end{tabular}

\section{DISCUSSION}

This paper presents the top six recommendations of the Romanian Choosing Wisely in Internal Medicine Campaign. This is a common effort of approximately $30 \%$ of the registered SRMI members.

\section{Particularities of the Romanian Choosing Wisely in Internal Medicine Campaign}

The Romanian Society of Internal Medicine adhered to the international initiative to reduce low-value care. Following examples from around the world, our Choosing Wisely campaign aimed to promote optimal use of the limited resources at our disposal.

Adopting the methodology proposed by the Italian Society of Internal Medicine [7], we set out to involve all members of our society, giving them the chance to vote for the recommendations acknowledged as most important. Compared to other societies' methodologies, where a group of opinion leaders chose the final recommendations, we considered this strategy to have a higher chance of long-term success in our country. By actively implicating the members of our society in selecting the recommendations, we not only obtained a general opinion with larger applicability but also raised awareness and reached out to a wider audience. Our 30\% response rate, although not high, surpassed the usually reported reply estimates.

A particularity of our campaign is the use of a social media site. Participants in the ranking process were not only the registered members of the Romanian Society of Internal Medicine, but also Internal Medicine and subspecialty physicians that were contacted via a social media platform. This approach allowed us to reach a broader group of doctors, especially junior physicians and young specialists. Nowadays, when social media is more and more involved in medical networking, information dissemination and professional interaction [10], we considered it a good opportunity to involve colleagues this way.

Involving these two groups of doctors into our campaign, we were able to compare and combine their ranking results. Although the age difference was significant, the main choices were similar in the two groups, reflecting a general tendency to acknowledge the importance of these recommendations.

Another particularity about our final recommendations is that they all refer to therapeutic measures. Possibly Romanian doctors may perceive their use of diagnostic procedures rational, or are not fully aware that diagnostic tests, like treatments, may be useless or even harmful. Only the Working Group ranked among their top recommendations those referring to the overuse of erythrocyte sedimentation rate alongside $\mathrm{C}$ reactive protein to detect inflammation and to the inappropriate use of D-dimer testing (Table 1), while the SRMI members did not.

Over the past years, Romania faced an excessive rate of inappropriate prescriptions as well as an alarming increase in antibiotic use without adequate indication. While opinion leaders are fighting this trend, many physicians are still widely prescribing unnecessary medication. We therefore consider these results as our respondents' recognition of the associated harm, as well as a means of raising further awareness regarding this problem.

Both the Choosing Wisely Working Group and the email and social media respondents rendered increased importance to this matter. Similarities were present regarding the general polypharmacy concept and the recommendations to permanently reassess the indication and benefit of each medication the patient receives, as well as regarding the use of antibiotics in patients with a history of Clostridium difficile infection or the use 
of red blood cells transfusions for anemia (Tables 1 and 4). Referring to specific treatment interventions with potentially harmful implications, there were considerable differences between the Working Group's top choices and the ones of the respondents. The former group ranked higher the recommendation regarding the potential risk of lipid-lowering medications in elderly patients and that of the association of angiotensin converting enzyme inhibitors with angiotensin II receptor blockers in treating hypertension, diabetic nephropathy or heart failure (Table 1). Meanwhile, the latter group ranked higher the recommendation referring to the potentially inadequate prescription of opioids for pain in patients with sensitive jobs (Table 4).

The similarities as well the differences between the top choices of the Working Group compared to those of the SRMI members are another particularity of our methodology. Although the main notions coincide, the Working Group seem to be more interested in tangible and specific interventions, while the SRMI members in more general and conceptual ones.

\section{The top six Choosing Wisely Romania - Internal Medicine recommendations}

Stop medicines when no further benefit is achieved or the potential harms outweigh the potential benefits for the individual patient

Division of internal medicine into subspecialties and the ageing population living with an increasing number of illnesses has led to multiple individual prescriptions by different specialists often overlooking the total number of preexisting medications. Furthermore, erroneous beliefs such as the patients' addressing the doctor in order to receive a new medication each time or that consults should implicitly lead to new prescriptions can lead to undesired negative outcomes [11].

Polypharmacy and potentially inappropriate medications are contemporary medical dilemmas with increasing prevalence, given the ageing population with multimorbid conditions. The myriad of unfavourable consequences such as adverse reactions, falls, confusion, or hospitalisation [11] are often overseen, leading to an increasing burden of negative healthcare outcomes [12]. Therefore, deprescribing may be an appropriate intervention in such cases [11]. Reeve et al. defined deprescribing as the process of withdrawal of an inappropriate medication, supervised by a health care professional with the goal of managing polypharmacy and improving outcomes [13].
In elderly patients, data from nonrandomized studies suggest that deprescribing reduces mortality and results of randomized trials correlate mortality reduction with patient-specific deprescribing interventions [14]. Both in the hospital [11] as well as in the primary care setting [15], tailored interventions for deprescribing and tapered cessation of medication seem safe and effective.

STOPP/START criteria for potentially inappropriate prescribing in older patients [16] may be effective in improving the quality of polypharmacy especially in elderly, frail adults [17]. The American Geriatrics Society 2015 Updated Beers criteria for potentially inappropriate medication use in older adults [18] could be another useful strategy for optimizing therapeutic interventions in elderly people [19].

The importance of this recommendation among Romanian physicians is highlighted by the fact that it ranked first among the respondents from the social media platform with an average score of 9.52 (Table 6) and second among respondents from the SRMI, with an average score of 9.39 (Table 5). It was also considered a priority by the Working Group, which ranked it 17 out of 200, with an average score of 8.37 (Table 1). More so, similar recommendations regarding polypharmacy, concurrent therapeutics and potentially inappropriate medication were also among the highest ranked by the Working Group, respectively items number 3, 7, 9, 24 and 25 from their top 36 (Table 1).

This recommendation was issued by the Australasian Society of Clinical and Experimental Pharmacologists and Toxicologists [5]. Similar recommendations are endorsed by the American Geriatrics Society [3], the Canadian Pharmacists Association [4], the Long-Term Care Medical Directors Associations of Canada [4], and the British Geriatrics Society [6], emphasizing the importance of rational prescribing and deprescribing for optimal patient care.

Don't use antibiotics in patients with recent $C$. difficile without convincing evidence of need. Antibiotics pose a high risk of $C$. difficile recurrence

Clostridium difficile infections (CDI) have a rising global incidence and increasing severity. This is also reflected by the infection's epidemiology in Romania. More so, in some specialized hospitals in our country, the infection's prevalence was higher than the mean European prevalence, predominantly associating a hypervirulent ribotype [20] that prompted specialists to highlight the need for antimicrobial stewardship. 
Antibiotic therapy is one of the most important risk factors for CDI. The risk is considerably greater if antimicrobial therapy is used after an episode of CDI, associating a 3-fold increase of the risk of recurrent disease [21], therefore warranting greater attention to adequate prescriptions. Along an age over 65 years, concomitant renal failure, use of antacid medication and initial disease severity, antibiotic treatment is one of the main risk factors for CDI recurrence [22]. In light of findings suggesting that more than a quarter of patients with a recent CDI still received unnecessary antibiotics [23], the Romanian Guidelines for Diagnosis, Treatment and Prevention of Clostridium difficile infections recommends careful consideration of antibiotic indication [24]. Also, if the patient's condition requires antimicrobial therapy, the first choice should be of a compound with the lowest risk for CDI, individualized for each case [24].

This recommendation ranked first among the SRMI participants with an average score of 9.48 (Table 5) and third among the social media participants, with an average score of 9.14 (Table 6). It also ranked $8^{\text {th }}$ out of 200 in the classification obtained from the Working Group, with an average score of 8.62 (Table 1). The increasing occurrence and the associated morbidity of CDI as well as the active involvement of Infectious Diseases specialists in raising awareness about this growing problem have reached the Romanian public. Physicians in our country are starting to fully understand the danger of inappropriate antibiotic use and its severe consequences, recurrent CDI being one of them.

The recommendation was issued by the Society for Healthcare Epidemiology of America [3] and was only present among the USA Choosing Wisely recommendations. Other indications regarding Clostridium difficile address the appropriate testing only when symptoms are present $[3,4]$ and the unnecessary testing for CDI resolution [3].

Don't regularly prescribe bed rest and inactivity following injury and/or illness unless there is scientific evidence that harm will result from activity. Promote early mobilization

The common misbelief that bed rest is beneficial in hospitalized patients has been contradicted for many years now. From 1999 physicians have rightfully questioned the efficacy of bed rest, and even more, raised the question of possible harm [25]. In critically ill patients bed rest was associated with catabolism, muscular atrophy and ICU-related weakness [26] as well as short- and long-term physical impairments and longer length of hospital stay [27].

ICU-related weakness - including critical illness polyneuropathy, critical illness myopathy and critical illness neuromyopathy - has a reported mean incidence of $40 \%$ in ICU patients. This is likely underestimated due to an impossible adequate examination of all patients at admission [28]. Early mobilisation and rehabilitation are safe and feasible interventions that can prevent these complications and improve patient care [27].

Specialized programs targeting early mobilization in frail elderly patients admitted to non-ICU departments have also shown a significant reduction in hospital-associated disability as well as the duration of hospital stay [29]. Inpatient mobilization enhances physical performance and also improves emotional and social well-being and overall better quality of care and general outcomes [30].

This recommendation ranked second among the respondents from the social media platform, with a mean score of 9.23 (Table 6), fifth among the SRMI members, with a mean score of 9.16 (Table 5) and $23^{\text {rd }}$ out of 200 among the Choosing Wisely Romania Working Group, with a mean score of 8.25 (Table 1). During the last two decades, physicians and nurses have proved and advocated the benefits of patient mobilization in contrast to the harm of prolonging bed rest. Recognizing the priority of recommendation and addressing this cultural shift is an important step in improving quality of care in Romania.

The Italian Society of Internal Medicine [7] issued the same recommendation, as did The American Academy of Nursing [3] and the Canadian Association of Physical Medicine and Rehabilitation [4]. More so, the American Academy of Physical Medicine and Rehabilitation [3] and the North American Spine Society [3] recommend caution and proper assessment of the indication of prolonged bed rest for back pain, while the American Physical Therapy Association [3] recommends bed rest after initiation of anticoagulant therapy for diagnosis of deep vein thrombosis only if significant medical concerns are present.

\section{Don't initiate an antibiotic without an identified indication and a predetermined length of treatment or review date.}

The discovery of antibiotics revolutionized medicine and saved millions of lives. The misuse of antibiotics, however, led to worldwide catastrophic consequences, antibiotic resistance and Clostridium difficile infections being two of the most important 
ones. As reported by the Center for Disease Control and Prevention, antibiotics are among the most commonly prescribed drugs, but up to $50 \%$ of these prescriptions are either unnecessary or not optimally effective as prescribed [31]. In this regard, problems extend from the improper indication of treatment, improper choice of antibiotic agent, improper dosing, route of administration and/or duration of therapy [32].

The repercussions are dire and, unfortunately, Romania seems to be one of the most affected countries in Europe, as reported by the European Centre for Disease Prevention and Control [33]. We are one of the European countries with the highest antibiotic resistance of bacteria such as Klebsiella pneumoniae, Pseudomonas aeruginosa, Acinetobacter species, Staphylococcus aureus and enterococci [33]. These multidrug-resistant germs pose a real threat to our patients and our healthcare system, warranting for wiser use of antibiotics. Microbiology and infectious diseases specialists are constantly evaluating the severity of this situation and raising awareness about the importance of adequate antibiotic treatment plans and infection control protocols [34, 35].

Antimicrobial stewardship programs were conceived to optimize the use of antibiotics using cost-effective instruments to diminish antibiotic resistance and prevent Clostridium difficile infections [36]. The principles of care implemented by these programs include recommendations to use, when possible, monotherapy instead of combination therapy, narrow instead of broad-spectrum antibiotics, oral instead of intravenous route of administration. They also underline the need for correct assessment and treatment of infection and not colonization, selection of antibiotics with the lowest Clostridium difficile inducing potential and limited use of antimicrobials with a high resistance potential [36].

This recommendation concisely sums the principles of antibiotic stewardship, as a step towards improving the quality of antimicrobial care in Romania. It was voted $6^{\text {th }}$ among the SRMI members with a mean score of 9.13 (Table 5) and $4^{\text {th }}$ among the social media platform respondents, with a mean score of 9.14 (Table 6). It also ranked $8^{\text {th }}$ of the 200 recommendations voted by the Working Group, with a mean score of 8.62 (Table 1). Since very few hospitals in Romania have antibiotic stewardship programs, the high ranking of this recommendation underlines the raising awareness of the dangers associated with inappropriate use as well the importance of adequate prescription of antimicrobial agents.
This recommendation was issued by the Society of Hospital Pharmacists of Australia [5]. Similar recommendations were endorsed by the Italian Society of Internal Medicine [7] and the Society for Healthcare Epidemiology of America [3]. Other Choosing Wisely recommendations targeting inappropriate use of antibiotics referred to treating asymptomatic bacteriuria only in pregnancy or in patients undergoing endoscopic urological procedures [3, 4, 9], not indicating antibiotics for uncomplicated upper respiratory tract infection [3, 4, 9], uncomplicated sinusitis [3] or bronchitis $[3,4]$.

\section{Don't prescribe opioids for treatment of chronic or acute pain for sensitive jobs such as operating motor vehicles, forklifts, cranes or other heavy equipment}

Pain is a significant determinant of quality of life, but also of burden of disability in the working population, making its management a global healthcare challenge [37]. One of the treatment options with significantly increased use lately is opioids. The growing number of prescriptions for noncancer pain associated increased morbidity and mortality linked to overdose, dependence or adverse effects such as urticaria, nausea and vomiting, constipation, dyspnea, respiratory failure and alteration of consciousness [37, 38].

Studies looking at injured workers receiving opioid prescriptions concluded that the majority of events related to the opioid use, diagnosed as either poisoning or adverse effects, occurred with lower doses than the guidelines consider potentially dangerous [39] and also associated with acute, not only with chronic use [40]. As such, authors emphasized the importance of raising awareness that even smaller doses and short-term use of opioids can have deleterious effects [39, 40]. More so, since dizziness, drowsiness and cognitive compromise are some of the most common side effects, workers taking opioids performing sensitive jobs such as operating motor vehicles, forklifts, cranes or other heavy equipment are prone to work-related accidents that can have severe consequences. Guidelines therefore recommend restricting the ability to operate such machinery or even drive while under opioid treatment [41].

Although opioid prescriptions are rather infrequent in Romanian workers, our physicians voted this recommendation most probably recognizing the potential harm they can cause to these patients. It ranked sixth in the classification from the social media platform, with an average score of 9.04 
(Table 6), and ninth among the SRMI members, with an average score of 9.11. The highest discordance was registered between the overall votes of the respondents compared to the Working Group's, which ranked this recommendation $27^{\text {th }}$, with an average score of 8.25 (Table 1).

The recommendation was first issued by the American College of Occupational and Environmental Medicine and the Occupational Medicine Specialists of Canada, societies from countries with the highest reported number of opioid prescriptions. Among the European Choosing Wisely recommendations, Romania is thus far the only country to adopt it among its most important ones.

Transfuse red cells for anemia only if the hemoglobin concentration is less than $7 \mathrm{~g} / \mathrm{dL}$ or if the patient is hemodynamically unstable or has significant cardiovascular or respiratory comorbidity. Don't transfuse more units of blood than absolutely necessary

Anemia has an increasing prevalence among inpatients, affecting up to $45 \%$ of hospitalized patients and up to two thirds of those admitted to the intensive care unit [42]. Subsequently, transfusion of red blood cells became one of the most frequent therapeutical procedures on the wards, both in internal medicine as well as surgery departments. Although it can often be lifesaving, this procedure can also cause significant harm to its recipients, especially if used inappropriately. Adverse reactions range from very severe ones such as anaphylaxis, acute or delayed hemolysis, septic transfusion reaction or transfusion-related lung injury to less severe ones such as non-hemolytic fever or urticaria $[43,44]$.

To improve quality of care by decreasing unnecessary interventions with potentially serious unwanted effects, recent evidence supports the use of restrictive transfusion thresholds, respectively a hemoglobin level less than $7 \mathrm{~g} / \mathrm{dL}$ in most cases [45]. Compared to a liberal, higher hemoglobin level of 9 to $10 \mathrm{~g} / \mathrm{dL}$ as an indication for transfusion, the restrictive level of 7 to $8 \mathrm{~g} / \mathrm{dL}$ considerably decreased the use of packed red blood cells with no difference in 30-day morbidity or mortality as reported in a recent systematic review [45].

For hospitalized adult patients that are hemodynamically stable, including critically ill patients, guidelines therefore recommend a restrictive transfusion threshold of $7 \mathrm{~g} / \mathrm{dL}$ [46]. For patients undergoing orthopaedic surgery, cardiac surgery as well for those with preexisting cardiovascular disease, the recommended restrictive transfusion threshold is $8 \mathrm{~g} / \mathrm{dL}$ [46]. However, in high-risk patients undergoing major surgery caution is required, as in some cases a liberal threshold could associate better outcomes $[47,48]$.

Strategies that improve outcomes in patients with anemia include not only lowering the threshold, but also limiting the number of transfused units of red blood cells [44]. Since fluid burden, especially in susceptible patients such as those with congestive heart or renal failure, can lead to transfusion-associated circulatory overload, continuous reassessment of the indication for transfusion and tailoring the therapy to the patient's clinical status are important steps in preventing adverse events [44].

Combining two synergistic approaches to optimizing red blood cell transfusion practice, this recommendation was voted as the sixth most important one by all responders with a mean score of 9.09 (Table 4), third by the SRMI members with a mean score of 9.26 (Table 5) and, discordantly, $18^{\text {th }}$ by the social media platform responders with a mean score of 8.51 (Table 6). From the initial voting round, this recommendation ranked first among the Working Group's classification, with a mean score of 9.37 and because of similarity, it was paired up with the $22^{\text {nd }}$ recommendation that had a mean score of 8.25 (Table 1). It is the only recommendation that received a significantly lower mean score from the social media platform responders, compared to all other groups of voting participants. However, we would like to emphasize its importance to clinical practice, especially since it is one the most prevalent recommendations among the Choosing Wisely campaigns from all over the world.

This recommendation is endorsed by the American Academy of Family Physicians [3], the Society of Hospital Medicine for Adult Medicine [3], the Critical Care Societies Collaborative [3], the American Society of Hematology [3], the Canadian Society of Internal Medicine [4], the Canadian Society for Transfusion Medicine [4], the Canadian Hematology Society [4], the Canadian Society of Palliative Care Physicians [4], the Australian and New Zealand Intensive Care Society [5], the Royal Australasian College of Surgeons [5], the United Kingdom Faculty of Intensive Care Medicine [6] and the Italian Federation of Associations of Hospital Doctors in Internal Medicine [8]. 


\section{CONCLUSIONS}

To set the premises for a better quality care, we should objectively and continuously evaluate the risk versus benefit ratios and appropriateness of our diagnostic or treatment recommendations and choose wisely what is best for each of our patients.

We should question the necessity of each indication we give to our patients and base our decisions on continuously updated evidence and guidelines. Medicine is ever changing and so should our knowledge and awareness of new discoveries and at the same time of new evidence supporting our daily practice. Quality of care is not synonymous to abundance of care, but to appropriate care individualized for each patient. And do not forget, primum non nocere.

Declaration of interest: The authors declare there is no conflict of interest.

Calitatea îngrijirilor medicale nu este necesar proporțională cantității, excesul fiind frecvent inutil sau, mai mult, potențial dăunător pacienților noştri. Aderând la inițiativa Federației Europene de Medicină Internă, Societatea Română de Medicină Internă (SRMI) a lansat campania Choosing Wisely - Să alegem înțelept - în Medicina Internă, scopul fiind de a scădea numărul procedurilor diagnostice sau terapeutice nenecesare, utilizate în exces în țara noastră. A fost inființat un Grup de Lucru şi din 200 recomandări publicate în campanii internaționale anterioare, 36 au fost votate drept cele mai importante. Acestea au fost trimise membrilor SRMI şi au fost postate pe o platformă media socială, pentru a fi votată importanța lor. După aceste două runde de vot au fost stabilite cele mai importante top şase recomandări. Acestea au fost:

1. Opriți tratamentele atunci când acestea nu mai aduc niciun beneficiu, sau efectele adverse potențiale depăşesc beneficiile pentru pacientul respectiv.

2. Nu prescrieți antibiotice unui pacient $\mathrm{cu}$ infecție recentă $\mathrm{cu}$ Clostridium difficile fără a vă convinge că acest lucru este cu adevărat necesar. Atibioticele cresc foarte mult riscul de recurență a infecției cu Clostridium difficile.

3. $N u$ prescrieți de rutină repaus la pat şi inactivitate fizică în caz de traumatism sau boală, dacă $n u$ există dovezi ştiintifice că activitatea dăunează pacientului respectiv. Promovați mobilizarea precoce.

4. Nu inițiați un tratament antibiotic fără a identifica mai întâi indicația şi durata predeterminată a tratamentului (sau data la care să reevaluați oprirea sau continuarea).

5. Nu prescrieți analgezice opioide pentru tratamentul durerii acute sau cronice lucrătorilor care efectuează munci ce necesită siguranță precum conducerea de vehicule cu motor, stivuitoare, macarale sau alte echipamente grele.

6. Transfuzați masă eritrocitară pentru anemie numai dacă hemoglobina este mai mică decât $7 \mathrm{~g} / \mathrm{dL}$, sau pacientul este hemodinamic instabil, sau are comorbidități semnificative cardiovasculare sau respiratorii. Nu transfuzați mai multe unități decât este absolut necesar.

Correspondence to: Prof. Cristian Baicus, Department of Internal Medicine, "Carol Davila” University of Medicine and Pharmacy, Colentina Clinical Hospital, 19-21 Stefan cel Mare St., 020121 Bucharest, Romania;

Tel.: +40788302355; fax: +40213180657 E-mail: cbaicus@gmail.com

\section{REFERENCES}

1. Choosing Wisely/Good Stewardship - National Physicians Alliance, Available at: http://npalliance.org/promoting-goodstewardship-in-medicine-project/ [accessed. 2018-10-07].

2. GOOD STEWARDSHIP WORKING GROUP. The "top 5" lists in primary care: meeting the responsibility of professionalism. Arch. Intern. Med. 2011;171(15):1385-90.

3. Choosing Wisely, Available at: http://www.choosingwisely.org/ [accessed. 2018-05-20].

4. Choosing Wisely Canada, Available at: https://choosingwiselycanada.org/ [accessed. 2018-05-20]. 
5. Choosing Wisely Australia, Available at: http://www.choosingwisely.org.au/home [accessed. 2018-05-20].

6. Choosing Wisely UK, Available at: http://www.choosingwisely.co.uk/ [accessed. 2018-05-20].

7. MONTANO, N., COSTANTINO, G., CASAZZA, G., SBROJAVACCA, R., LENTI, M.V., FALSETTI, L., et al. The Italian Society of Internal Medicine choosing wisely campaign. Intern. Emerg. Med. 2016;11(8):1125-1130.

8. LUSIANI, L., FREDIANI, R., NARDI, R., FONTANELLA, A., CAMPANINI, M. Doing more does not mean doing better: The FADOI contribution to the Slow Medicine program for a sustainable and wise healthcare system. Ital. J. Med. 2015;9(3):281-286.

9. SELBY, K., GASPOZ, J.-M., RODONDI, N., NEUNER-JEHLE, S., PERRIER, A., ZELLER, A., et al. Creating a list of lowvalue health care activities in Swiss primary care. JAMA Intern. Med. 2015;175(4):640.

10. CHAN, W.S., LEUNG, A.Y. Use of Social Network sites for communication among health professionals: systematic review. J. Med. Internet Res. 2018;20(3):e117.

11. THILLAINADESAN, J., GNJIDIC, D., GREEN, S., HILMER, S.N. Impact of deprescribing interventions in older hospitalised patients on prescribing and clinical outcomes: a systematic review of randomised trials. Drugs Aging 2018;35(4):303-319.

12. SCOTT, I.A., ANDERSON, K., FREEMAN, C.R., STOWASSER, D.A. First do no harm: a real need to deprescribe in older patients. Med. J. Aust. 2014;201(7):390-2.

13. REEVE, E., GNJIDIC, D., LONG, J., HILMER, S. A systematic review of the emerging definition of "deprescribing" with network analysis: implications for future research and clinical practice. Br. J. Clin. Pharmacol. 2015;80(6):1254-68.

14. PAGE, A.T., ClifFORD, R.M., POTTER, K., SCHWARTZ, D., ETHERTON-BEER, C.D. The feasibility and effect of deprescribing in older adults on mortality and health: a systematic review and meta-analysis. Br. J. Clin. Pharmacol. 2016;82(3):583-623.

15. THIO, S.L., NAM, J., VAN DRIEL, M.L., DIRVEN, T., BLOM, J.W. Effects of discontinuation of chronic medication in primary care: a systematic review of deprescribing trials. Br. J. Gen. Pract. 2018;68(675):e663-e672.

16. O'MAHONY, D., O'SULLIVAN, D., BYRNE, S., O'CONNOR, M.N., RYAN, C., GALLAGHER, P. STOPP/START criteria for potentially inappropriate prescribing in older people: version 2. Age Ageing 2014;44(2):213-218.

17. HILL-TAYLOR, B., WALSH, K.A., STEWART, S., HAYDEN, J., BYRNE, S., SKETRIS, I.S. Effectiveness of the STOPP/START (Screening Tool of Older Persons' potentially inappropriate Prescriptions/Screening Tool to Alert doctors to the Right Treatment) criteria: systematic review and meta-analysis of randomized controlled studies. J. Clin. Pharm. Ther. 2016;41(2):158-169.

18. BY THE AMERICAN GERIATRICS SOCIETY 2015 BEERS CRITERIA UPDATE EXPERT PANEL. American Geriatrics Society 2015 updated beers criteria for potentially inappropriate medication use in older adults. J. Am. Geriatr. Soc. 2015;63(11):2227-2246.

19. LEVY, H.B. Polypharmacy reduction strategies. Clin. Geriatr. Med. 2017;33(2):177-187.

20. POPESCU, G.A., SERBAN, R., PISTOL, A., NICULCEA, A., PREDA, A., LEMENI, D., et al. The recent emergence of Clostridium difficile infection in Romanian hospitals is associated with a high prevalence of polymerase chain reaction ribotype 027. Balkan Med. J. 2018;35(2):191-195.

21. DREKONJA, D.M., AMUNDSON, W.H., DECAROLIS, D.D., KUSKOWSKI, M.A., LEDERLE, F.A., JOHNSON, J.R. Antimicrobial use and risk for recurrent Clostridium difficile infection. Am. J. Med. 2011;124(11):1081.e1-1081.e7.

22. SMITS, W.K., LYRAS, D., LACY, D.B., WILCOX, M.H., KUIJPER, E.J. Clostridium difficile infection. Nat. Rev. Dis. Prim. 2016;2:16020.

23. SHAUGHNESSY, M.K., AMUNDSON, W.H., KUSKOWSKI, M.A., DECAROLIS, D.D., JOHNSON, J.R., DREKONJA, D.M. Unnecessary Antimicrobial use in patients with current or recent Clostridium difficile infection. Infect. Control Hosp. Epidemiol. 2013;34(02):109-116

24. POPESCU, G.-A., CODIȚĂ, I., TĂLĂPAN, D., ŞERBAN, R., RUJA, G. Ghid de diagnostic, tratament şi prevenire a infecțiilor determinate de Clostridium difficile (Ediția a 2-a). b.n. Available at: http://mainicurateinspitale.ro/wpcontent/uploads/2016/08/Ghid-diagnostic-tratament-si-prevenire-Clostridium-difficile.pdf.

25. ALLEN, C., GLASZIOU, P., DEL MAR, C. Bed rest: a potentially harmful treatment needing more careful evaluation. Lancet (London, England) 1999;354(9186):1229-33.

26. LIPSHUTZ, A.K.M., GROPPER, M.A. Acquired neuromuscular weakness and early mobilization in the intensive care unit. Anesthesiology 2013;118(1):202-215.

27. HASHEM, M.D., PARKER, A.M., NEEDHAM, D.M. Early mobilization and rehabilitation of patients who are critically ill. Chest 2016;150(3):722-31.

28. APPLETON, R.T., KINSELLA, J., QUASIM, T. The incidence of intensive care unit-acquired weakness syndromes: A systematic review. J. Intensive Care Soc. 2015;16(2):126-136.

29. SURKAN, M.J., GIBSON, W. Interventions to Mobilize elderly patients and reduce length of hospital stay. Can. J. Cardiol. 2018;34(7):881-888.

30. KALISCH, B.J., LEE, S., DABNEY, B.W. Outcomes of inpatient mobilization: a literature review. J. Clin. Nurs. 2014;23(1112):1486-1501.

31. CENTERS FOR DISEASE CONTROL AND PREVENTION. Antibiotic resistance threats in the United States. b.n.Available at: https://www.cdc.gov/drugresistance/pdf/ar-threats-2013-508.pdf.

32. ASLAM, B., WANG, W., ARSHAD, M., KHURSHID, M., MUZAMMIL, S., RASOOL, M., et al. Antibiotic resistance: a rundown of a global crisis. Infect. Drug Resist. 2018;11:1645-1658.

33. EUROPEAN CENTRE FOR DISEASE PREVENTION AND CONTROL. ECDC: SURVEILLANCE REPORT. Surveillance of antimicrobial resistance in Europe 2016, b.n., B.m., 2016.

34. LIXANDRU, B., COTAR, A., STRAUT, M., USEIN, C., CRISTEA, D., CIONTEA, S., et al. Carbapenemase-producing Klebsiella pneumoniae in Romania: A six-month survey. PLoS One 2015;10(11):e0143214. 
35. GAVRILIU, L., POPESCU, G., POPESCU, C. Antimicrobial resistance of Pseudomonas aeruginosa in a Romanian hospital at the dawn of multidrug resistance. Brazilian J. Infect. Dis. 2016;20(5):509-510.

36. CUNHA, C. Antimicrobial stewardship programs: principles and practice. Med. Clin. North Am. 2018;102(5):797-803.

37. MANCHIKANTI, L., KAYE, A., KNEZEVIC, N., MCANALLY, H., SLAVIN, K., TRESCOT, A., et al. Responsible, safe, and effective prescription of opioids for chronic non-cancer pain: American Society of Interventional Pain Physicians (ASIPP) Guidelines. Pain Physician 2017;20(2S):S3-S92.

38. ELS, C., JACKSON, T., KUNYK, D., LAPPI, V., SONNENBERG, B., HAGTVEDT, R., et al. Adverse events associated with medium- and long-term use of opioids for chronic non-cancer pain: an overview of Cochrane Reviews. Cochrane Database Syst. Rev. 2017;10:CD012509.

39. FULTON-KEHOE, D., GARG, R., TURNER, J., BAUER, A., SULLIVAN, M., WICKIZER, T., et al. Opioid poisonings and opioid adverse effects in workers in Washington State. Am. J. Ind. Med. 2013;56(12):1452-1462.

40. LEE, S., CHOI, Y., PRANSKY, G. Extent and impact of opioid prescribing for acute occupational low back pain in the emergency department. J. Emerg. Med. 2016;50(3):376-384.e2.

41. HEGMANN, K., WEISS, M., BOWDEN, K., BRANCO, F., DUBRUELER, K., ELS, C., et al. ACOEM GUIDELINES ACOEM Practice guidelines: opioids and safety-sensitive work. JOEM 2014;56(7):e46-53.

42. DOCHERTY, A., TURGEON, A., WALSH, T. Best practice in critical care: anaemia in acute and critical illness. Transfus. Med. 2018;28(2):181-189.

43. DELANEY, M., WENDEL, S., BERCOVITZ, R., CID, J., COHN, C., DUNBAR, N., et al. Transfusion reactions: prevention, diagnosis, and treatment. Lancet 2016;388(10061):2825-2836.

44. CARSON, J., TRIULZI, D., NESS, P. Indications for and adverse effects of red-cell transfusion. N. Engl. J. Med. 2017;377(13):1261-1272.

45. CARSON, J., STANWORTH, S., ROUBINIAN, N., FERGUSSON, D., TRIULZI, D., DOREE, C., et al. Transfusion thresholds and other strategies for guiding allogeneic red blood cell transfusion. Cochrane Database Syst. Rev. 2016;10:CD002042.

46. CARSON, J., GUYATT, G., HEDDLE, N., GROSSMAN, B., COHN, C., FUNG, M., et al. Clinical practice guidelines from the AABB. JAMA 2016;316(19):2025.

47. HOVAGUIMIAN, F., MYLES, P. Restrictive versus liberal transfusion strategy in the perioperative and acute care settings: a context-specific systematic review and meta-analysis of randomized controlled trials. Anesthesiology 2016;125(1):46-61.

48. GU, W.-J., GU, X.-P., WU, X.-D., CHEN, H., KWONG, J.S.W., ZHOU, L.-Y., et al. Restrictive versus liberal strategy for red blood-cell transfusion: a systematic review and meta-analysis in orthopaedic patients. J. Bone Joint Surg. Am. 2018; 100(8):686-695.

Received January 2, 2019 